\title{
Inter-annual and inter-specific differences in the drift of fish eggs and yolksac larvae in the North Sea: A biophysical modeling approach
}

\author{
MYRON A. PECK ${ }^{1}$, WILFRIED KÜHN ${ }^{2}$, HANS-HARALD HINRICHSEN ${ }^{3}$ \\ and THOMAS POHLMANN ${ }^{2}$ \\ ${ }^{1}$ Center for Marine and Climate Research, Institute of Hydrobiology and Fisheries Science, University of Hamburg, \\ Olbersweg 24, D-22767, Hamburg, Germany. E-mail: myron.peck@ uni-hamburg.de \\ ${ }^{2}$ Center for Marine and Climate Research, Institute of Oceanography, University of Hamburg, \\ Bundesstraße 53, D-20146, Hamburg, Germany. \\ ${ }^{3}$ Leibniz Institute of Marine Sciences at the University of Kiel (IfM GEOMAR), \\ Düsternbrooker Weg 20, D-24105, Kiel, Germany.
}

SUMMARY: We employed 3-D biophysical modeling and dispersion kernel analysis to explore inter-annual and interspecific differences in the drift trajectories of eggs and yolksac larvae of plaice (Pleuronectes platessa), Atlantic cod (Gadus morhua), sprat (Sprattus sprattus) and horse mackerel (Trachurus trachurus) in the North Sea. In this region, these four species exhibit peak spawning during the boreal winter, late winter/early spring, late spring/early summer, and mid-summer respectively, but utilize the same spawning locations (our simulations included Dogger Bank, Southern Bight and the German Bight). Inter-annual differences in the temperature history, and an increase in the area of dispersion and final distribution at the end of the yolksac phase were more pronounced (and related to the North Atlantic Oscillation) for winter- and early spring-spawners compared to late spring/summer spawners. The progeny of the latter experienced the largest (up to 10-fold) inter-annual differences in drift distances, although absolute drift distances were modest ( 2 to $30 \mathrm{~km}$ ) when compared to those of the former ( 20 to $130 \mathrm{~km})$. Our results highlight the complex interplay that exists between the specific life history strategies of the different species and the impacts of the variability in (climate-driven) physical factors during the earliest life stages of marine fish.

Keywords: IBMs, marine fish, life history strategy, drift, temperature, water currents.

RESUMEN: DiFERENCIAS INTERANUALES E INTERESPECÍFICAS EN LA DERIVA DE HUEVOS Y LARVAS LECITOTRÓFICAS EN EL MAR DE NORTE: APROXIMACIÓN A TRAVÉS DE UN MODELO BIOFísICO. - En este trabajo utilizamos un modelo 3-D físico-biológico y un análisis de dispersión del núcleo para investigar las diferencias interespecíficas e interanuales en las trayectorias de la deriva de huevos y larvas lecitotróficas de la solla (Pleuronectes platessa), el bacalao Atlántico (Gadus morhua), el espadín (Sprattus sprattus) y el jurel (Trachurus trachurus) en el Mar del Norte. En esta región, las especies estudiadas muestran distintos picos de distintos desoves en el tiempo: invierno boreal, invierno tardío/primavera temprana, primavera tardía/verano temprano y mitad del verano, respectivamente, aunque comparten las mismas zonas de desove. Las simulaciones efectuadas corresponden a tres de estas zonas: Dogger Bank, Southern Bight y German Bight. Los resultados mostraron diferencias interanuales en la temperatura experimentada por las larvas, en el área de dispersión y en el patrón de distribución al final del estadio lecitotrófico, que fueron más evidentes en el bacalao Atlántico, en comparacion con el espadín. Así mismo, estos factores estuvieron correlacionados con la Oscilación del Atlántico Norte. La progenie del espadín, además, mostró la mayor variación interanual en la distancia de dispersión, siendo hasta 10 veces mayor, aunque la distancia absoluta alcanzada fue relativamente modesta $(\sim 2-30 \mathrm{~km})$ en comparación con la observada para el bacalao Atlántico $(\sim 20-130 \mathrm{~km})$. Nuestros resultados subrayan la compleja interacción que existe, durante los estadios tempranos del desarrollo de peces marinos, entre las estrategias ecológicas específicas de las distintas especies y el impacto de la variabilidad de los factores físicos, modulados a su vez por el clima.

Palabras clave: IBMs, peces marinos, estrategias ecológicas, dispersión, temperatura, corrientes marinas. 


\section{INTRODUCTION}

The phenology of maturation and spawning in temperate, shelf-sea marine fish species is endogenously regulated and often cued by seasonal changes in environmental factors such as water temperature and photoperiod duration interacting with food availability (Cushing, 1969). Some marine fish species utilize the same spawning location year after year. This spawning site fidelity has probably "evolved" as an adaptive strategy to place progeny within environments that promote high rates of feeding, survival and growth during early life, and consequently a high probability of life cycle closure and recruitment success (e.g. Cushing, 1969; Ellertsen et al., 1989). In some marine fishes, pelagic eggs and larvae have relatively long drift phases in the plankton, and are subject to variable hydrographic situations, and survival may depend upon the arrival of late-stage larvae at specific, suitable juvenile nursery areas (e.g. Harden-Jones, 1968). This scenario is particularly common for species that spawn at times of the year when water temperatures are relatively low. In other fish species, retention within specific regions appears to be a key factor (Iles and Sinclair, 1982). In fact, the interrelationships among many physical and biological processes appear to be important for high rates of survival and growth of marine fish early life stages, and a myriad of recruitment hypotheses have emerged based on research on different species in different environments (for a review see Houde, 2008).

Pelagic fish eggs and larvae in the North Sea can experience a highly dynamic hydrographic environment due to the interaction of tides and river runoff with topographic features. For example, tidal-mixing areas and frontal zones can be extremely productive habitats that support a high biodiversity of marine fauna including relatively dense aggregations of larval fish, their prey and their predators (Kiørboe et al., 1988; Riegman et al., 1990; Munk et al., 1999; Floeter, 2005). These physical features of the environment are directly impacted by changes in climate forcing (e.g. air temperature and wind velocity) and the relationship between climate variability and productivity in North Sea fish fauna has been recognized and studied for more than 100 years. The fact that many fish exist at their (either high or low) latitudinal extreme in the North Sea is a second feature that makes the composition of the fish assemblage dynamic with respect to climatic changes (Beare et al., 2004; Alheit et al., 2007). Given the pronounced seasonality in physical and biological factors in the North Sea system, species that spawn at different times of the year have probably adopted quite different (yet successful) life history strategies that make them either more or less vulnerable to climate-driven changes in hydrography and prey fields.

Observed changes in the composition of the North Sea fish assemblage have been driven by both commercial exploitation (Daan et al., 2005; Heath, 2005) and concomitant changes in climate (Beare et al., 2004). In terms of climate impacts, long-term changes have been observed at all trophic levels (e.g. from phytoplankton to fish), have often appeared as regime shifts (e.g. in the mid 1980s), and have been strongly associated with climate variability expressed by the North Atlantic Oscillation (NAO) (Reid et al., 2001; Beaugrand et al., 2003). Among other trends in North Sea fish species, the most recent decade has been characterized by strongly decreasing stocks of gadoids, a re-colonization of the North Sea by spawning populations of warmer water clupeiform fishes such as European anchovy (Engraulis encrasicolus) and sardine (Sardina pilchardus) (Beare et al., 2004; Alheit et al., 2007; Kanstinger and Peck, 2009) and a general northward shift of two thirds of the commercially-important stocks (Perry et al., 2005).

The present study was motivated by these recent changes in the North Sea fish community and employed a biophysical model to examine the potential inter-annual and inter-specific differences in the impact of (climate-driven) abiotic factors on the drift of endogenously-feeding, pelagic life stages (eggs and yolksac larvae). Our modeling approach combined knowledge on the effects of temperature on the developmental rates of the species studied and information on spawning times and locations to compare the drift of early life stages of plaice (Pleuronectes platessa), Atlantic cod (Gadus morhua), sprat (Sprattus sprattus) and horse mackerel (Trachurus trachurus). These four species were chosen because they are all commercially-important, exhibit peak spawning activity at the same locations but at different times of the year, and have different life history strategies. Drift trajectories (final position and relative size of distributional area) were quantified using dispersion kernel analysis. We also examined how drift trajectories differ among three important North Sea spawning locations (Dogger Bank, Southern Bight, and German Bight). Finally, we examined whether inter-annual differences in drift trajectories could be correlated with inter-annual differences in the NAO-Index. This 
study is part of a much larger project evaluating potential climate impacts on European fish and shellfish resources ("RECLAIM", EU $6^{\text {th }}$ framework program) and takes one step towards this goal by examining variability in the duration and trajectories of drift of early life stages in light of differences in life cycle scheduling and developmental physiology.

\section{MATERIALS AND METHODS}

\section{Hydrodynamic model}

Drift simulations were conducted using the threedimensional, baroclinic shallow-water circulation model HAMSOM (Backhaus, 1985), which has been modified with respect to the transport equation for temperature and salinity and formulation of vertical eddy viscosity. A detailed description of these modifications and a validation of the turbulence closure scheme have been provided by Pohlmann (1996). This version of HAMSOM was employed to simulate hydro- and thermodynamic processes in the southern and central North Sea taking into account all relevant driving mechanisms (Pohlmann, 2006). The simulation period covers 1970 to 2005. The model equations are formulated using a spherical grid of $2.5^{\prime}$ X $1.5^{\prime}$ in longitudinal and meridional direction, respectively, which is sufficient to resolve mesoscale processes. The grid covers the area from the Strait of Dover in the south to a line running from the northern tip of Denmark westwards to the Scottish coast (Fig. 1). In the vertical, a z-coordinate system is employed to resolve the water column in a maximum number of 21 layers. Because processes in the upper part of the water column, particularly near the thermocline, have the smallest scales, the upper 10 internal boundaries are only $5 \mathrm{~m}$ apart. Below $50 \mathrm{~m}$ and down to the maximum depth of $160 \mathrm{~m}$ the vertical resolution is $10 \mathrm{~m}$. At open boundaries, sea surface elevations and temperature and salinity distributions were provided by a model covering the entire North Sea. The latter was in turn embedded in a hydrodynamic model for the entire Northwest-European Shelf (Fig. 1, insert). This nesting approach allowed the intermediate model to provide the heat and salinity fluxes needed at the open boundaries of the mesoscale North Sea model (i.e. sea surface elevation - a measure for vertically-integrated geostrophic transport, and temperature and salinity distributions). All three hydrodynamic models were

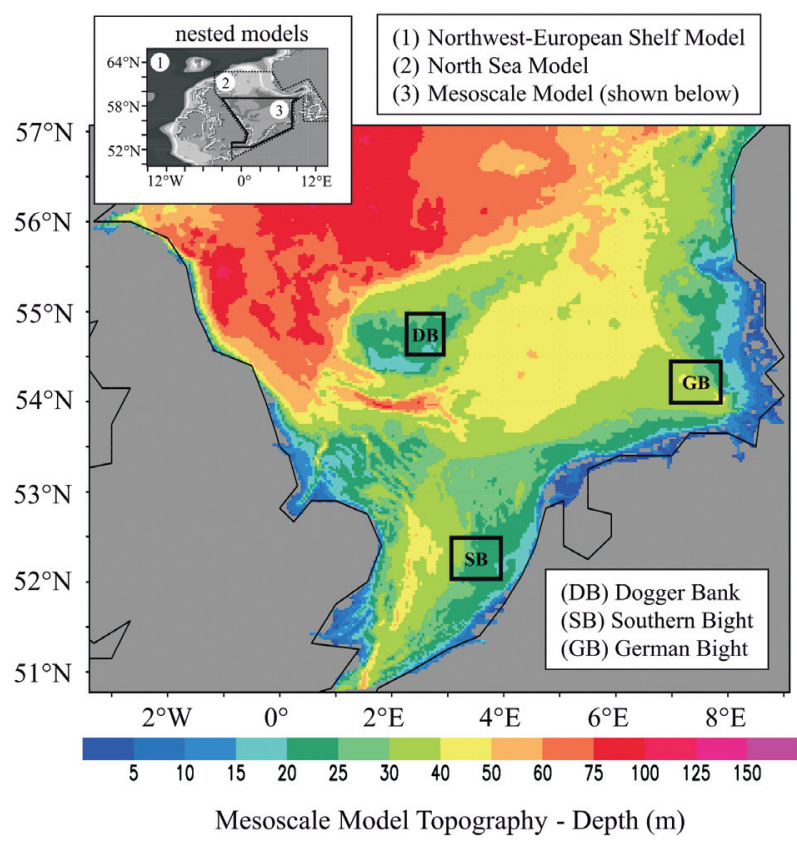

FIG. 1. - Nested model domains (insert) and bottom topography of the meso-scale version of the 3-d hydrodynamic model HAMSOM employed in the present study. The positions of the three spawning (particle release) areas (Dogger Bank, Southern Bight, and German Bight) are also indicated.

forced by meteorological re-analysis data provided by NCAR/NCEP (Kalnay et al., 1996).

A Lagrangian drift model was applied based on the output of HAMSOM (daily mean values of velocities, eddy diffusion coefficients, temperature). Horizontal and vertical diffusion was included by applying a diffusive random walk algorithm using a Monte-Carlo method (Visser, 1997). Relatively small daily mean values $\left(10 \mathrm{~m}^{2} \mathrm{~s}^{-1}\right)$ were employed for horizontal diffusion to mimic daily fluctuations of the velocity.

\section{Biological subroutine}

The effect of temperature on the duration of the egg stage (time to hatch) of plaice, Atlantic cod, sprat and horse mackerel has been previously quantified and, in most cases, so has the influence of water temperature on the duration of the yolksac larval phase (Table 1). The duration of the yolksac phase of Atlantic cod $\left(2.0\right.$ to $\left.12.0^{\circ} \mathrm{C}\right)$ and horse mackerel $(13.0$ to $24.0^{\circ} \mathrm{C}$ ) was taken from a generalized equation describing the exponential decrease in the duration of the yolksac stage ( $Y_{\text {DUR }}$, time to $5 \%$ yolk remaining) of 39 marine fish species in 19 families with increasing water temperature $(T)\left(Y_{\text {DUR }}=775.4 \mathrm{e}^{-0.099 * T}\right.$, $\mathrm{r}^{2}$ adj $=0.702, \mathrm{n}=139, \mathrm{p}<0.0001$, M.A. Peck unpublished data). In the present simulations, the effect 
TABLE 1. - Summary of the impacts of temperature $\left(\mathrm{T},{ }^{\circ} \mathrm{C}\right)$ on the duration (days) of the egg and yolksac larvae of plaice (Pleuronectes platessa), Atlantic cod (Gadus morhua), sprat (Sprattus sprattus) and horse mackerel (Trachurus trachurus). Equations $\left(\mathrm{Y}=\mathrm{a} T^{\mathrm{b}}\right)$ describing the development rate $\left(\% \mathrm{~d}^{-1}\right)$ of the complete endogenous feeding period are also provided. In all cases, $\mathrm{p}<0.001$.

\begin{tabular}{|c|c|c|c|c|c|c|c|c|c|c|}
\hline \multirow{2}{*}{$\begin{array}{l}\text { Developmental } \\
\text { Stage Estimate }\end{array}$} & \multirow{2}{*}{$\begin{array}{l}\text { Equation } \\
\text { ID }\end{array}$} & \multirow{2}{*}{$\begin{array}{c}\text { Species } \\
\text { common name }\end{array}$} & \multirow{2}{*}{\multicolumn{2}{|c|}{ Temperatures }} & \multicolumn{4}{|c|}{$\underset{\mathrm{a}}{\operatorname{Regression} \text { Parameters }}\left(\underset{\mathrm{b}}{\mathrm{Y}}=\mathrm{aT}^{\mathrm{b}}\right)$} & \multicolumn{2}{|c|}{ Statistics } \\
\hline & & & & $\begin{array}{l}\text { ratures } \\
\text { max }\end{array}$ & mean & SE & mean & SE & $\mathrm{n}$ & $\mathrm{r}^{2}$ adj \\
\hline Egg duration (d) & $\begin{array}{l}\# 1 \\
\# 2 \\
\# 3 \\
\# 4\end{array}$ & $\begin{array}{c}\text { Plaice } \\
\text { Atlantic cod } \\
\text { Sprat } \\
\text { Horse Mackerel }\end{array}$ & $\begin{array}{c}2.0 \\
1.0 \\
4.0 \\
10.4\end{array}$ & $\begin{array}{l}12.0 \\
14.0 \\
12.0 \\
21.2\end{array}$ & $\begin{array}{l}77.75 \\
34.68 \\
77.01 \\
525.4\end{array}$ & $\begin{array}{c}4.90 \\
1.96 \\
3.35 \\
112.50\end{array}$ & $\begin{array}{l}-0.854 \\
-0.539 \\
-1.263 \\
-1.890\end{array}$ & $\begin{array}{l}0.031 \\
0.028 \\
0.017 \\
0.069\end{array}$ & $\begin{array}{c}62 \\
68 \\
19 \\
6\end{array}$ & $\begin{array}{l}0.925 \\
0.847 \\
0.996 \\
0.993\end{array}$ \\
\hline $\begin{array}{l}\text { Yolksac larval } \\
\text { duration (d) }\end{array}$ & $\begin{array}{l}\# 5 \\
\# 6 \\
\# 7 \\
\# 8\end{array}$ & $\begin{array}{c}\text { Plaice } \\
\text { Atlantic cod } \\
\text { Sprat } \\
\text { Horse Mackerel }\end{array}$ & $\begin{array}{l}2.6 \\
4.0\end{array}$ & $\begin{array}{l}9.8 \\
\text { (inte } \\
12.0 \\
\text { (inte }\end{array}$ & $\begin{array}{l}34.35 \\
\text { cific equ } \\
69.43 \\
\text { cific equ }\end{array}$ & $\begin{array}{l}3.32 \\
\text { ation, se } \\
16.49 \\
\text { tion, se }\end{array}$ & $\begin{array}{l}-0.645 \\
\text { ext) } \\
-0.851 \\
\text { ext) }\end{array}$ & $\begin{array}{l}0.050 \\
0.092\end{array}$ & $\begin{array}{c}6 \\
19\end{array}$ & $\begin{array}{l}0.970 \\
0.996\end{array}$ \\
\hline $\begin{array}{l}\text { Development rate } \\
\text { of eggs }+ \text { yolksac } \\
\text { larvae }\left(\% \mathrm{~d}^{-1}\right)\end{array}$ & $\begin{array}{c}\# 9 \\
\# 10 \\
\# 11 \\
\# 12\end{array}$ & $\begin{array}{c}\text { Plaice } \\
\text { Atlantic cod } \\
\text { Sprat } \\
\text { Horse Mackerel }\end{array}$ & $\begin{array}{c}2.0 \\
2.0 \\
4.0 \\
13.0\end{array}$ & $\begin{array}{l}12.0 \\
12.0 \\
18.0 \\
23.0\end{array}$ & $\begin{array}{l}0.903 \\
0.923 \\
0.716 \\
0.131\end{array}$ & $\begin{array}{c}\text { na } \\
0.037 \\
\text { na } \\
0.012\end{array}$ & $\begin{array}{l}0.774 \\
0.822 \\
1.000 \\
1.609\end{array}$ & $\begin{array}{c}\text { na } \\
0.021 \\
\text { na } \\
0.032\end{array}$ & $\begin{array}{r}\text { (analytical s } \\
11 \\
\text { (analytical s } \\
11\end{array}$ & $\begin{array}{r}2=1.0) \\
0.993 \\
2=1.0) \\
0.996\end{array}$ \\
\hline
\end{tabular}

Data references were: plaice (von Westernhagen, 1970; Ryland and Nichols, 1975; Fox et al., 2003); Atlantic cod (Nissling, 2004; Jordaan and Kling, 2003; Geffen et al., 2006); sprat (Thompson et al., 1981; Nissling, 2004; Petereit et al., 2008); horse mackerel (Pipe and Walker, 1987).

of temperature on the rate of development $(D E V, \%$ $\mathrm{d}^{-1}=100 *$ duration $^{-1}$ ) was calculated from the sum of the temperature-specific durations of both the egg and yolksac larval phases (Table 1). Due to the species-specific slope of the $D E V$ versus $T$ relationship (b-values in Table 1), the relative impact of warming is species-specific with the absolute increase in $D E V$ depends upon where the change occurs in the tolerable range in temperatures. The biological subroutine calculated the daily percentage development completed by particles as a function of mean water temperature experienced that day (daily percentage calculated according to Eqs 9, 10, 11 and 12, see Table 1). A cumulative percentage development was calculated as the sum of daily percentages accrued by that particle based on temperatures experienced on previous days. The particle position was fixed on the day when $100 \%$ development was obtained.

\section{Drift simulations}

We assessed the drift trajectories and durations of the endogenously-feeding life stages of plaice, Atlantic cod, sprat and horse mackerel eggs and yolksac larvae at 480, evenly-spaced, horizontal grid locations at each of three release sites: Dogger Bank (DB, 2.04 to $2.83^{\circ} \mathrm{E}$ and 54.40 to $54.98^{\circ} \mathrm{N}$ ), German Bight $\left(\mathrm{GB}, 7.04\right.$ to $7.83^{\circ} \mathrm{E}$ and 54.02 and $\left.54.48^{\circ} \mathrm{N}\right)$ and Southern Bight (SB, 3.04 to $3.83^{\circ} \mathrm{E}$ and 51.9 to 52.48). At each grid location at each of the three sites, particles were released at $5 \mathrm{~m}$ depth intervals that, in most cases, represented five different depths
$(2.5,7.5,12.5,17.5$ and $22.5 \mathrm{~m})$. An unequal number of particles was released at the 480 locations at each site $(\mathrm{DB}=2188, \mathrm{SB}=2338 \mathrm{~m} \mathrm{~GB}=1900)$ due to differences in the total depth of release locations. During the simulations, particles were not fixed to these depths, rather depth varied due to the impacts of vertical eddy viscosity and vertical diffusion. The simulations were started on calendar day 1 (1 January), day 75 (15 March), day 135 (15 May) and day 196 (15 July) for plaice, Atlantic cod, sprat and horse mackerel, respectively. These dates were chosen due to the peak spawning times of these species in the North Sea (e.g. Harding et al., 1978; Munk, 1993; Rogers et al., 2001; ICES, 2007). As previously mentioned, the duration of drift was equal to the time required for $100 \%$ development.

Simulations were conducted for each of the four species released (spawned) on Dogger Bank in 1988, 1989, 1995, 1996 and 2001 to make inter-annual comparisons. Spatial comparisons were made by releasing particles at each of the three spawning locations (Dogger Bank, German Bight and Southern Bight) in two years (1995 and 1996). Finally, additional releases were made at Dogger Bank for Atlantic cod and sprat during 1985, 1986, 1991 and 2004 to create a longer time series that could be compared to inter-annual differences in the North Atlantic Oscillation (NAO) index.

During the simulation, the location, depth and mean temperature of each particle were recorded each day along with its cumulative percentage development. We limited our simulations to the end 
of the yolksac phase to exclude any marked influence of behavior (e.g. diel vertical migration or directed swimming) that could influence particle drift trajectories. Although the buoyancy of eggs and yolksac larvae is known to change slightly during early development (e.g. Coombs et al., 1990 and 2004), for these simulations we assumed that they had neutral buoyancy.

\section{Analysis procedure}

The distribution of individuals at the end of the endogenous-feeding period was characterized with simple statistical parameters including principal component analysis (PCA). Edwards et al. (2007) quantitatively estimated the retention or dispersion of larval fish from spawning grounds by calculating dispersal kernels, the density of settling particles at a given location normalized to the number of released particles. They calculated five parameters: 1) mean distance traveled, 2) the direction relative to the starting position, variances of 3) the major and 4) the minor axis of variability of the spatial distribution of a larval cohort, and 5) the principal angle or the orientation of the major axis. The last three parameters were obtained from the ending positions of the particles using PCA (Preisendorfer, 1988), and provided a two dimensional statistical description of the kernel.

In contrast to Edwards et al. (2007), who released drift particles at a single location, we calculated dispersal kernels for particles released on a grid of locations representing a spawning aggregation/area. Ensemble averaging of drift distances from the center of spawning activity of many individual trajectories enabled the main drift direction to be calculated. The drift velocity $\left(D_{V E L}, \mathrm{~km} \mathrm{~d}^{-1}\right)$ was calculated as the mean drift distance $\left(D_{D I S}\right)$ divided by the mean drift duration $\left(D_{D U R}\right.$, days). To account for very slight differences in the size of the three release areas, the spread amount $(S A)$ was always expressed in relative units (final ellipse size divided by the size of the release area). Retention was designated if a portion of the final ellipse remained in the spawning area and/ or the $S A$ remained relatively small. Based on $S A$ and $D_{D U R}$, a spreading velocity $\left(S V=S A^{*} D_{D U R}{ }^{-1}\right)$ was also calculated. For each species, the magnitude of interannual differences in drift attributes $\left(D_{D I S}, D_{V E L}, S A\right.$ and $S V$ ) were computed using the coefficient of variation $\left(C V=\mathrm{SD}^{*} \mathrm{mean}^{-1}\right)$. Furthermore, Pearson correlation coefficients were calculated for each of the drift parameters and the NAO winter index.

\section{RESULTS}

\section{Comparisons among species and years on Dogger Bank}

Due to differences in the release (peak spawning) times used in the Dogger Bank simulations, markedly different mean water temperatures were experienced among the species that, in most cases, were close to the middle of the range in tolerable temperatures for each species (Fig. 2). Inter-annual differences (among the five years) in mean water temperatures experienced during the drift of all particles (eggs and larvae) were relatively modest for plaice $(\mathrm{CV}=6.5 \%)$ and horse mackerel $(\mathrm{CV}$ $=4.5 \%)$, larger in sprat $(\mathrm{CV}=8.4 \%)$ and most marked for Atlantic cod (CV $=14.9 \%)$ (Fig. 3). In Atlantic cod, mean temperatures were $4{ }^{\circ} \mathrm{C}$ lower in 1996 leading to a mean $( \pm$ SD) drift duration of $31.8( \pm 1.1)$ days compared to $22.9( \pm 0.3)$ days in the warmest year $\left(1989,6.8( \pm 0.1)^{\circ} \mathrm{C}\right)$. Early life stages of plaice generally experienced water temperatures that declined $1{ }^{\circ} \mathrm{C}$ during their drift period (mean 23.6 to 26.4 days), whereas sprat ex-

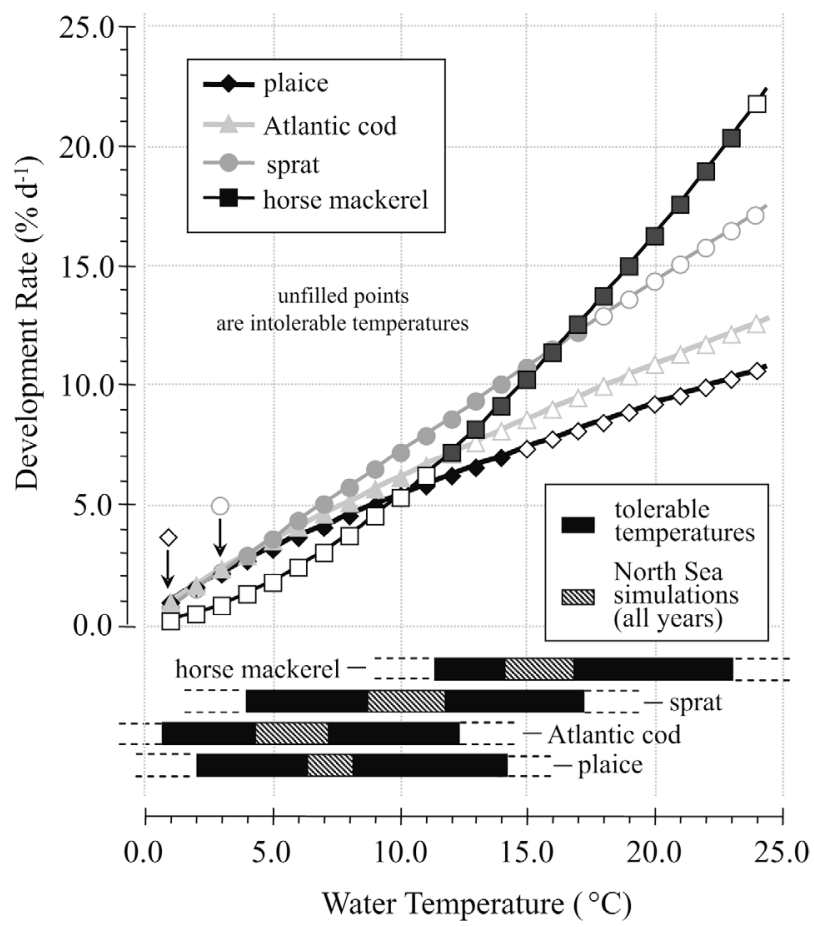

FIG. 2. - Rate of development $\left(\% \mathrm{~d}^{-1}\right)$ versus water temperature $\left({ }^{\circ} \mathrm{C}\right)$ for plaice (diamonds), Atlantic cod (triangles), sprat (circles), and horse mackerel (squares). Intolerable temperatures are indicated using unfilled symbols. The range in tolerable water temperatures (black bar) and the range in temperatures experienced during North Sea drift simulations (lined area) are also shown. Note, eggs were released on one spawning date each year for each species. 


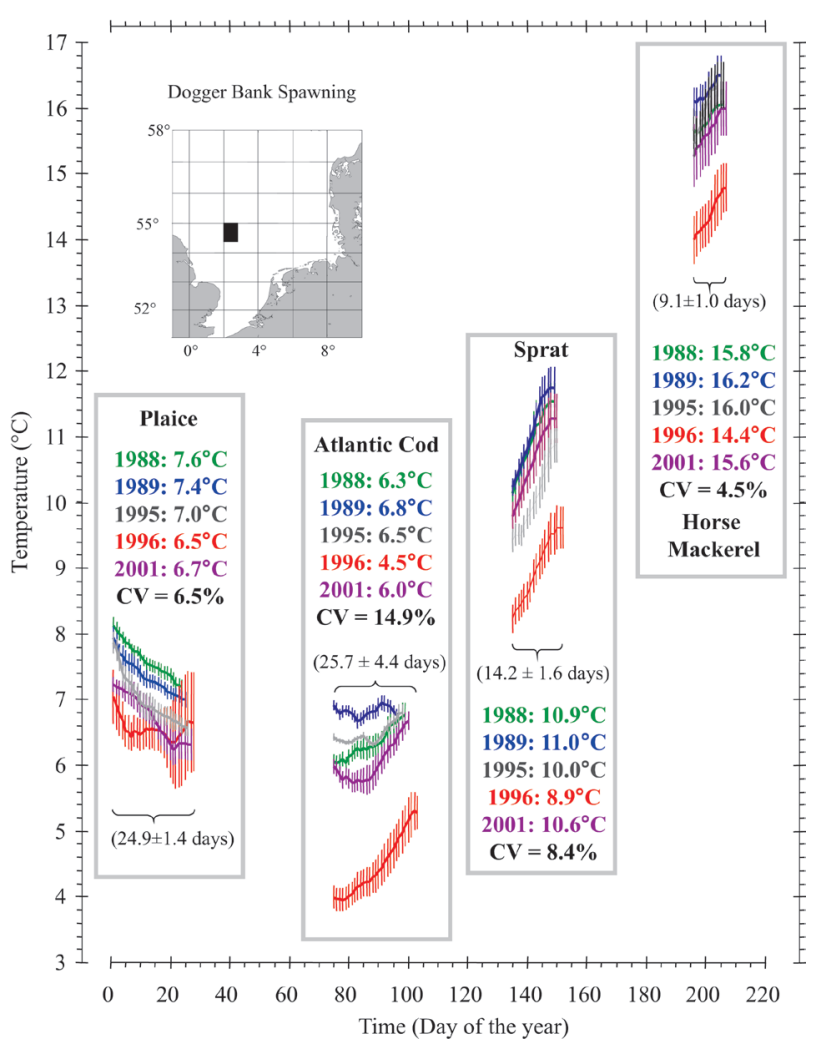

FIG. 3. - Mean temperatures experienced during the drift of 2188 particles (eggs and yolksac larvae) of plaice, Atlantic cod, sprat and horse mackerel released on day 0 , day 75 , day 135 and day 196 respectively, on Dogger Bank (insert) in each of the five years. Mean temperatures (averaged over the entire drift phase) and mean $( \pm$ range) in drift duration for the five years are also provided.

perienced a 1.5 to $2.0^{\circ} \mathrm{C}$ increase during the drift phase (mean 13.1 to 16.2 days). Horse mackerel experienced water temperatures between $\sim 14.0$ and $16.5^{\circ} \mathrm{C}$ and had a relatively brief drift phase (mean 9.0 to 11.1 days) prior to the exhaustion of yolk reserves (Fig. 3).

The exponential increase in development rate (decrease in drift duration) with increasing temperature and the different mean water temperatures experienced during peak spawning contributed to markedly different drift characteristics among the four species (Fig. 4). For example, the mean $( \pm \mathrm{SD})$ drift distance $\left(D_{D I S}\right)$ was $97.6( \pm 30.3), 48.2( \pm 30.7)$, $21.1( \pm 6.7)$ and $12.2( \pm 9.8) \mathrm{km}$ for plaice, Atlantic cod, sprat and horse mackerel, respectively (Fig. 4a). After normalizing for differences in drift duration, the mean $( \pm \mathrm{SD})$ drift velocity was not equal among all species but was greatest for plaice $(3.9( \pm 1.1) \mathrm{km}$ $\mathrm{d}^{-1}$ ) compared to the other three species (between 1.3 and $\left.1.9 \mathrm{~km} \mathrm{~d}^{-1}\right)$ (Fig. 4b). The mean $( \pm \mathrm{SD})$ spreading amount was $360( \pm 150), 276( \pm 60) 150( \pm 10)$ and $130( \pm 10) \%$ for plaice, Atlantic cod, sprat and
(A)
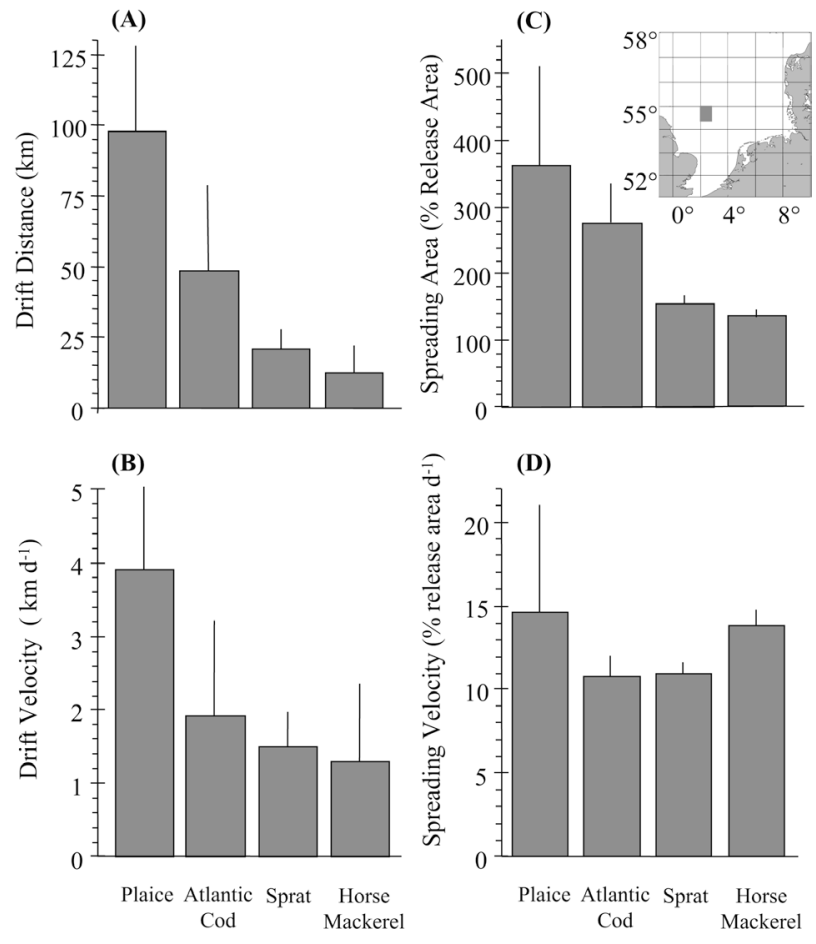

FIG. 4. - Summary characteristics of the dispersion of eggs and yolksac larvae of plaice, Atlantic cod, sprat and horse mackerel released on 1 January, 15 March, 15 May and 15 July respectively at Dogger Bank (North Sea). Values of mean drift distance (panel A), drift velocity (panel B), relative spreading area (panel C) and spreading velocity of particles (panel d) are means $(+\mathrm{SE})$ of the results of releases made in five years $(1988,1989,1995,1996$ and 2001).

horse mackerel, respectively (Fig. 4c). However, after normalizing for differences in drift duration, the spreading velocity $\left(\% \mathrm{~d}^{-1}\right)$ was similar among the species and between 10 and $15 \% \mathrm{~d}^{-1}$ (Fig. 4d). These inter-specific differences were largely driven by our choice of spawning (release) time since water temperature alone explained $\sim 50 \%$ of the variance in mean drift distance (Fig. 5a) and the factor increase in spreading area (Fig. 5b) among the species, the latter due to drift duration. Among all species, the mean factor increase in spreading area was positively related to the mean drift distance (Fig. 6). Plaice and Atlantic cod (the species released at relatively cold water temperatures and that had relatively long drift durations) exhibited the largest inter-annual difference in spreading area ( 4-fold difference). In contrast, sprat and horse mackerel (the species that experienced relatively warm water temperatures and which had short drift durations and small absolute drift distances) had the largest inter-annual difference in relative distance traveled $(\sim 10$-fold difference) (Fig. 6).

In terms of final drift location, for spawning on Dogger Bank in each of the five years, the fi- 

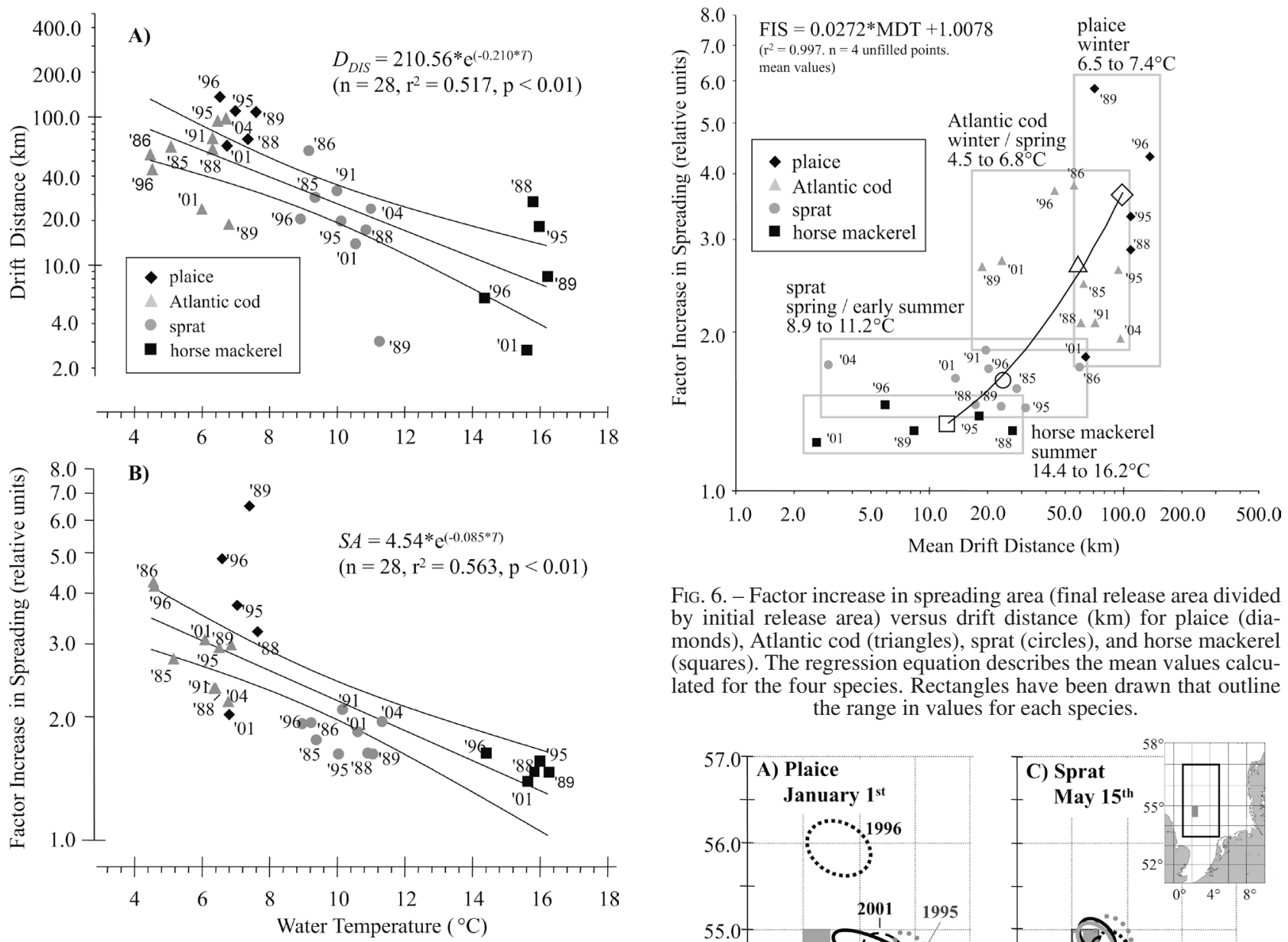

FIG. 5. - Changes in drift distance $(\mathrm{km})$ (Panel A) and factor increase in dispersion area (final area divided by release/spawning area) (Panel B) versus water temperature for plaice (diamonds), Atlantic cod (triangles), sprat (circles), and horse mackerel (squares). Regression equations are for the pooled data. Note that the ordinate axis has a log scale in both panels.

nal dispersion kernel ellipse areas overlapped in 0, 2, 4 and 4 years for plaice, Atlantic cod, sprat and horse mackerel, respectively (Fig. 7a-d). Conversely, among the five years for each species, the final position of the dispersion kernel was unique in only one year for plaice but in three of the years for Atlantic cod. In sprat and horse mackerel, the kernel areas overlapped (at least partially) in each of the five years. During the five years, ellipses for plaice, Atlantic cod, sprat and horse mackerel overlapped (at least partially) with the spawning area (a situation defined as retention) in 0, 3, 4 and 5 years, respectively (Fig. 7a-d).

\section{Comparison among spawning locations}

Spawning location impacted the strength of inter-annual differences in drift durations, drift

FIG. 6. - Factor increase in spreading area (final release area divided by initial release area) versus drift distance $(\mathrm{km})$ for plaice (diamonds), Atlantic cod (triangles), sprat (circles), and horse mackerel (squares). The regression equation describes the mean values calculated for the four species. Rectangles have been drawn that outline the range in values for each species.
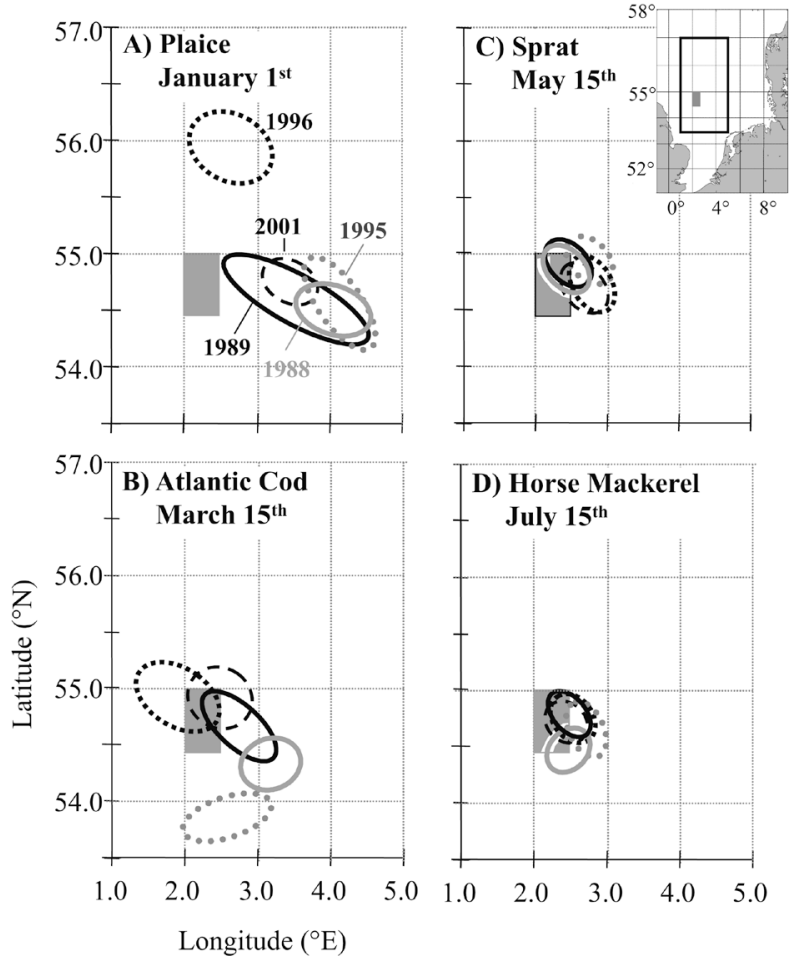

FIG. 7. - Dispersion kernels describing the final location of drifting eggs and yolksac larvae of plaice (Panel A), Atlantic cod (B), sprat (C) and horse mackerel (D) on Dogger Bank (insert map provided). The results for five different years are shown in each panel.

trajectories and final positions at the end of the yolksac phase. In general, winter/spring temperatures were lower and drift durations much longer in the German Bight than in the Southern Bight 
30 - M.A. PECK et al.

TABLE 2. - Mean water temperatures and drift durations experienced by plaice and sprat eggs and yolksac larvae released at three different spawning locations in the North Sea. The range in mean temperatures for $>2100$ particles at each location is also provided. Drift simulations for plaice and sprat started on 1 January and 15 May respectively.

\begin{tabular}{|c|c|c|c|c|c|c|c|}
\hline \multirow[t]{2}{*}{ Species } & \multirow[t]{2}{*}{ Year } & \multicolumn{2}{|c|}{$\begin{array}{l}\text { Dogger Bank } \\
(\text { mean } \pm \text { range })\end{array}$} & \multicolumn{2}{|c|}{$\begin{array}{l}\text { Southern Bight } \\
\text { (mean } \pm \text { range) }\end{array}$} & \multicolumn{2}{|c|}{$\begin{array}{l}\text { German Bight } \\
\text { (mean } \pm \text { range) }\end{array}$} \\
\hline & & $\mathrm{T}\left({ }^{\circ} \mathrm{C}\right)$ & Dur. (d) & $\mathrm{T}\left({ }^{\circ} \mathrm{C}\right)$ & Dur. (d) & $\mathrm{T}\left({ }^{\circ} \mathrm{C}\right)$ & Dur. (d) \\
\hline Plaice & $\begin{array}{l}1995 \\
1996\end{array}$ & $\begin{array}{l}7.0 \pm 0.4 \\
6.5 \pm 0.8\end{array}$ & $\begin{array}{l}25.0 \pm 1.0 \\
26.4 \pm 2.5\end{array}$ & $\begin{array}{l}7.3 \pm 1.0 \\
5.4 \pm 2.0\end{array}$ & $\begin{array}{c}24.3 \pm 2.5 \\
31.1 \pm 13.0\end{array}$ & $\begin{array}{l}5.6 \pm 1.5 \\
2.4 \pm 2.0\end{array}$ & $\begin{array}{c}30.1 \pm 7.5 \\
64.6 \pm 33.5\end{array}$ \\
\hline Sprat & $\begin{array}{l}1995 \\
1996\end{array}$ & $\begin{array}{c}10.0 \pm 0.7 \\
8.9 \pm 1.4\end{array}$ & $\begin{array}{l}14.5 \pm 1.0 \\
16.2 \pm 1.0\end{array}$ & $\begin{array}{l}11.7 \pm 0.8 \\
10.1 \pm 0.8\end{array}$ & $\begin{array}{l}12.5 \pm 1.0 \\
14.3 \pm 1.5\end{array}$ & $\begin{array}{l}10.3 \pm 1.3 \\
8.5 \pm 1.6\end{array}$ & $\begin{array}{l}14.1 \pm 1.5 \\
17.1 \pm 3.0\end{array}$ \\
\hline
\end{tabular}
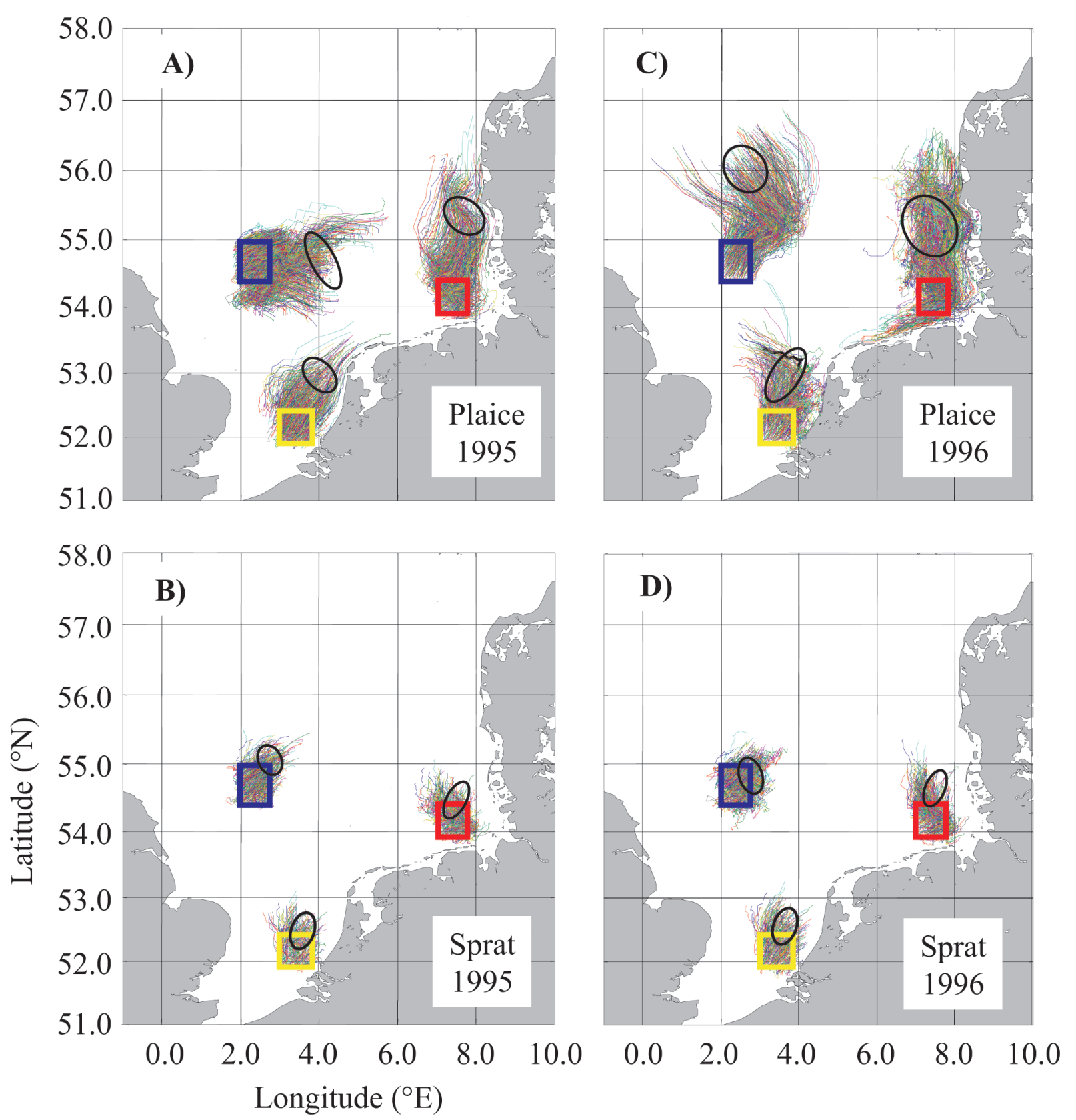

FIG. 8. - Comparison of drift trajectories of endogenous feeding stages (eggs and yolksac larvae) of plaice and sprat released at three spawning sites (black squares). The ensemble mean location at the end of the yolksac phase is represented by a dispersion ellipse (note, many individual trajectories overlay one another, obscuring the mean trajectory). Specific information regarding drift trajectories is provided in Table 2. 
or on Dogger Bank (Table 2). Mean temperatures experienced by drifting plaice in 1995 and 1996 in the German Bight were 2 to $3^{\circ} \mathrm{C}$ colder than the other areas. Mean temperatures during drift from the three spawning areas in the same year for sprat differed moderately (generally $<1.5^{\circ} \mathrm{C}$ ). In terms of drift trajectories, plaice eggs spawned on Dogger Bank and in the Southern Bight tended to drift towards the German Bight, and eggs released in the German Bight often remained there or, as in 1995, moved somewhat north into Danish coastal waters (Fig. 8a,b). Similar patterns emerged in 1996 except for plaice on Dogger Bank that drifted to the northwest (Fig. 8c). In sprat, differences in the final position at each of the three locations in these two years (1995 vs. 1996) were subtler (Fig 8b, d). In sprat for both years and each location, the areas of the dispersion kernel ellipse overlapped with the initial spawning location.

\section{Comparisons with Climate/NAO Index}

A total of eight years was simulated for Atlantic cod and sprat released on Dogger Bank and interannual differences were compared with the winter (November to February) index of the North Atlantic Oscillation (NAO). For Atlantic cod, negative NAO years were associated with relatively low temperatures and relatively large ellipse areas $(+400 \%$ of the initial spawning area) (Table 3, Fig. 9a). The most positive NAO years were clearly the warmest and characterized by particle retention (relatively small ellipse areas). However, years with the smallest ellipse areas were relatively "average" NAO years. In sprat, years with a high NAO index $(>1.5)$ had the smallest ellipse areas ( $145 \%$ initial release area) but these years were not necessarily the warmest (Table 3, Fig. 9b). For both species, years that did not have a strong (either positive or negative) NAO index could be characterized as either relatively warm or cold years and years with relatively strong retention (small ellipse areas overlapping with spawning areas) or dispersion (large ellipse areas, no spawning area overlap). Although the NAO was clearly linked to the duration of the endogenous feeding period in both species (due to the influence of the NAO on water temperature, especially for Atlantic cod), only the north-south distance of dispersion kernel statistics for sprat was significantly correlated $(\mathrm{p}<0.05)$ with values of the winter NAO index for both species (Table 3 ).

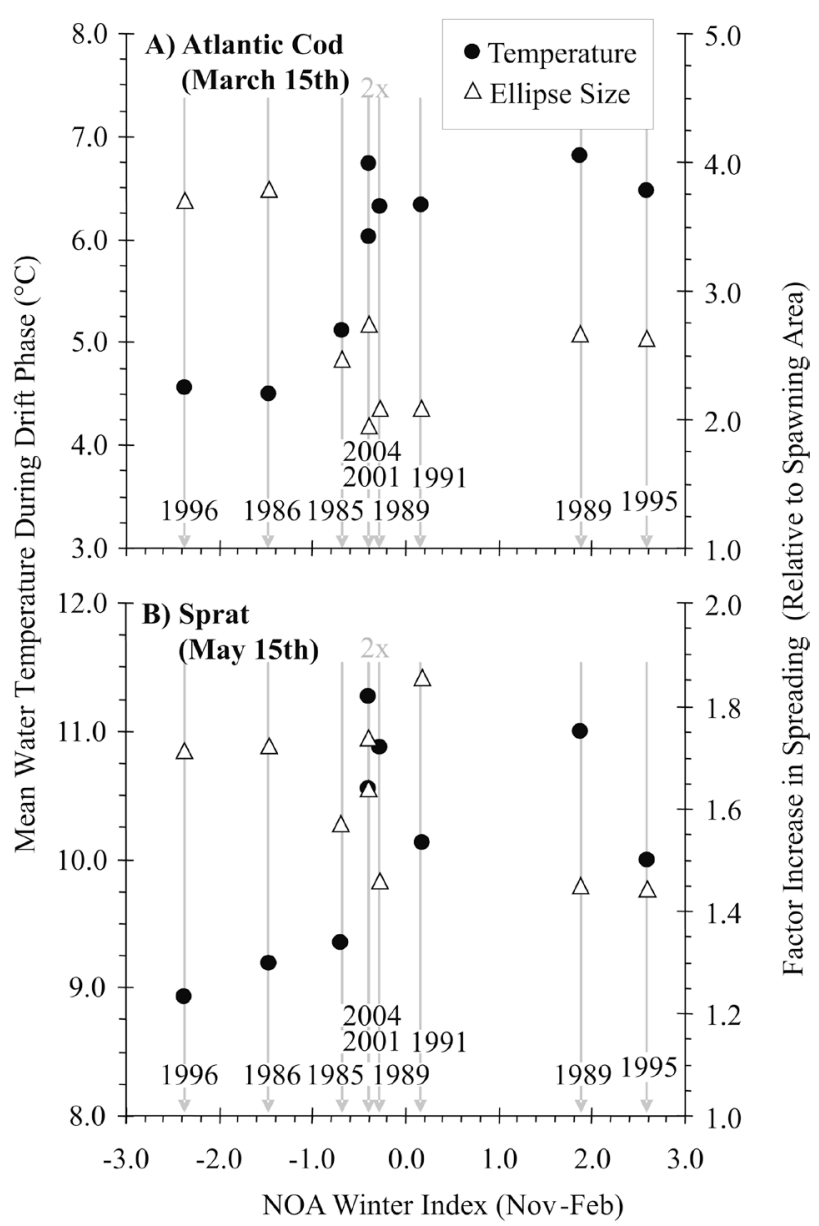

FIG. 9. - Summary information for the relationship between temperature $\left({ }^{\circ} \mathrm{C}\right.$, circles) and relative final ellipse size (\% size of spawning area, triangles) versus the winter index of the North Atlantic Oscillation. Data were calculated in each of nine years for Atlantic cod (panel A) and sprat (panel B) spawned on Dogger Bank in the North Sea. The years are indicated.

\section{DISCUSSION}

Given the pronounced seasonality in physical and biological factors of the North Sea system, fish species that spawn at different times of the year have probably adopted quite different (yet successful) life history strategies. These different life history strategies (e.g. timing and location of spawning) may make some species either more or less vulnerable to climate-driven changes in hydrography and prey fields. As a first step towards understanding the interplay between life history strategy and the impacts of (climate-driven) changes in key abiotic factors, we employed biophysical individual-based modeling to explore patterns in the drift of marine fish early life stages. Although IBMs have been utilized to examine drift of pelagic eggs and larvae in a variety of marine fish species (for review see Miller, 2007), the vast majority of these studies fo- 
TABLE 3. - Summary information for drift results for Atlantic cod and sprat in each of nine years. Also provided are the Pearson correlation coefficients of each measure with the winter North Atlantic Oscillation (NAO) index (values provided). Significant correlations are indicated $(*)$.

\begin{tabular}{|c|c|c|c|c|c|c|c|c|c|}
\hline \multirow[b]{2}{*}{ Year } & \multirow{2}{*}{$\begin{array}{l}\text { NAO } \\
\text { Winter } \\
\text { Index }\end{array}$} & \multirow{2}{*}{$\begin{array}{l}\text { Temp. } \\
\left({ }^{\circ} \mathrm{C}\right)\end{array}$} & \multirow{2}{*}{$\begin{array}{c}\text { Drift } \\
\text { Duration } \\
\text { (days) }\end{array}$} & \multirow{2}{*}{$\begin{array}{c}\text { Ellipse } \\
\text { Area } \\
(\%)\end{array}$} & \multirow{2}{*}{$\begin{array}{c}\text { Spreading } \\
\text { Rate } \\
\left(\% \mathrm{~d}^{-1}\right)\end{array}$} & \multicolumn{3}{|c|}{$\begin{array}{c}\text { Dispersion Kernel Statistics } \\
\text { Distance Traveled }{ }^{1}\end{array}$} & \multirow{2}{*}{$\begin{array}{l}\text { Speed }{ }^{1} \\
\left(\mathrm{~km} \mathrm{~d}^{-1}\right)\end{array}$} \\
\hline & & & & & & $\begin{array}{l}\text { North-South } \\
\quad(\mathrm{km})\end{array}$ & $\begin{array}{l}\text { East-West } \\
\quad(\mathrm{km})\end{array}$ & $\begin{array}{l}\text { Total } \\
(\mathrm{km})\end{array}$ & \\
\hline \multicolumn{10}{|c|}{ Atlantic Cod } \\
\hline 1985 & -0.69 & 5.11 & 28.9 & 246.9 & 8.5 & 24.3 & 57.4 & 62.4 & 2.2 \\
\hline 1986 & -1.46 & 4.50 & 32.0 & 379.4 & 11.8 & 19.4 & 52.3 & 55.8 & 1.7 \\
\hline 1988 & -0.27 & 6.32 & 24.4 & 208.8 & 8.6 & 40.3 & 44.9 & 60.4 & 2.5 \\
\hline 1989 & 1.88 & 6.82 & 22.9 & 266.6 & 11.6 & 4.4 & 18.1 & 18.6 & 0.8 \\
\hline 1991 & 0.18 & 6.34 & 24.3 & 209.1 & 8.6 & 1.0 & 71.2 & 71.2 & 2.9 \\
\hline 1995 & 2.59 & 6.47 & 24.0 & 262.8 & 11.0 & 94.1 & 6.3 & 94.3 & 3.9 \\
\hline 1996 & -2.36 & 4.55 & 31.8 & 370.9 & 11.7 & 25.2 & 36.4 & 44.3 & 1.4 \\
\hline 2001 & -0.39 & 6.03 & 25.3 & 274.1 & 10.8 & 23.6 & 0.2 & 23.6 & 0.9 \\
\hline 2004 & -0.39 & 6.74 & 23.0 & 194.6 & 8.5 & 29.0 & 92.3 & 96.8 & 4.2 \\
\hline \multicolumn{2}{|c|}{ NAO Correlation } & $0.764 *$ & $-0.754 *$ & -0.458 & 0.024 & 0.429 & -0.401 & 0.159 & 0.288 \\
\hline \multicolumn{10}{|l|}{ Sprat } \\
\hline 1985 & -0.69 & 9.35 & 15.44 & 156.9 & 10.2 & 22.8 & 16.6 & 28.2 & $\begin{array}{l}2.2 \\
1.7\end{array}$ \\
\hline 1986 & -1.46 & 9.19 & 15.85 & 172.1 & 10.9 & 1.1 & 59.0 & 59.0 & $\begin{array}{l}1.7 \\
2.5\end{array}$ \\
\hline 1988 & -0.27 & 10.88 & 13.23 & 145.7 & 11.0 & 17.1 & 2.1 & 17.2 & 2.5 \\
\hline 1989 & 1.88 & 11.00 & 13.10 & 144.8 & 11.1 & 23.3 & 1.6 & 23.4 & 0.8 \\
\hline 1991 & 0.18 & 10.13 & 14.21 & 185.6 & 13.1 & 12.8 & 14.7 & 19.5 & 2.9 \\
\hline 1995 & 2.59 & 10.00 & 14.46 & 144.2 & 10.0 & 25.3 & 18.1 & 31.2 & 3.9 \\
\hline 1996 & -2.36 & 8.93 & 16.22 & 171.2 & 10.6 & 1.6 & 20.0 & 20.1 & 1.4 \\
\hline 2001 & -0.39 & 10.56 & 13.82 & 163.9 & 11.9 & 1.2 & 13.6 & 13.6 & 0.9 \\
\hline 2004 & -0.39 & 11.27 & 13.03 & 173.6 & 13.3 & 0.1 & 3.0 & 3.0 & 4.2 \\
\hline \multicolumn{2}{|c|}{ NAO Correlation } & 0.503 & -0.65 & -0.591 & -0.09 & $0.727 *$ & -0.394 & -0.073 & 0.289 \\
\hline
\end{tabular}

cus on only one species and can involve complex biological subroutines (e.g. Daewel et al., 2008). In contrast, the present study utilized a biophysical model that had relatively simple biological characteristics in order to make an inter-specific comparison of basic features of egg and larval drift. In the following section, we discuss our drift results in relation to life history strategy within and between species. We also comment on the potential complexity of the interplay between life history strategy and species-specific impacts of climate variability and, in doing so, provide a critique of our relatively simple approach.

\section{North Sea winter and early spring spawners}

Plaice spawns in the Channel and southern North Sea from December until March (Harding et al., 1978) while Atlantic cod spawns a bit later (February to April). Both of these species exhibit spawning site fidelity. Tagging studies of plaice have revealed a close proximity of annual spawning locations by specific females on Dogger Bank (see Hunter et al., 2003). Similarly, a recent survey of Atlantic cod eggs suggested that spawning was restricted to a number of relatively small "pockets" of activity in the North Sea including regions of Dogger Bank and different areas within the German
Bight (Fox et al., 2008). Importantly, the results of that survey suggested that the traditional spawning sites of cod are still being utilized despite poor recruitment in recent years (ICES, 2005). Our drift simulation employed some of the known spawning sites for these species and suggest a high degree of inter-annual variability in both the duration of drift (time until end of endogenous yolk reserves) and the location of larvae at the point when first feeding must be initiated (end of yolksac phase).

For species that spawn in the winter/early spring, eggs and yolksac larvae will travel relatively large distances ( $>80 \mathrm{~km}$ in most years, Fig. 4a) before yolks are exhausted. In plaice and Atlantic cod, the duration of this endogenous feeding period (three to four weeks) is roughly one third to one quarter of the time required for larval of these species to metamorphose into young juveniles in the North Sea and adjacent areas. Therefore, large drift distances of passive early life stages are possible in some years and our simulation results suggest a high probability of population mixing from different spawning aggregations. These results explain, in part, the apparent paradox of genetic similarity among populations of plaice between the Bay of Biscay (Spain/France) and the Lofoten area (Norway) (Hoarau et al., 2002) and for Atlantic cod in the North Sea and Skagerrak area (Knutsen et al., 2004) despite observations of separate sub-populations that exhibit 
a high degree of spawning site fidelity. Plaice represent a special case of a winter/early spring spawning species since late stage larvae and early juveniles have extremely specific habitat requirements. In the southern North Sea, pelagic eggs and larvae of plaice drift towards extensive nursery grounds and larvae may enter coastal waters of Belgium, Holland, Germany or Denmark and settle on tidal flats in near-shore sandy bottoms as early as late February.

In the present simulations, plaice exhausted their yolk reserves at 3 to 4 weeks post-fertilization and, based on the development times of eggs and larvae (see Table 1, compare Eqs. 1 and 5), most of the drift $(\sim 75 \%)$ occurred during the egg stage. Given the relatively short drift phase after hatch prior to yolk exhaustion ( 7 to 10 days), our Dogger Bank simulation clearly indicated that successful first-feeding and foraging by larvae will be important well before this species reaches nursery grounds at a reported age of 8 to 10 weeks post-hatch. Our simulations also suggested that spawning by this species in the Southern Bight and German Bight (even during extreme NAO years such as 1996) would result in drift towards nursery areas (Wadden Sea, German Bight). However, this was not the case for spawning on Dogger Bank where strong northward drift, away from favorable nursery areas, was predicted in 1996. Furthermore, of the four species examined, intra-annual (among-individual) variability in water temperature was greatest in plaice during 1996 (see error bars in Fig. 3). Although plaice eggs and yolksac larvae generally experienced decreasing water temperatures during development, some plaice (particularly during cold years in the German Bight) experienced extremely low temperatures $\left(<1.5^{\circ} \mathrm{C}\right.$, see Table 2$)$ that would directly lower the probability of survival (Fox et al., 2003).

\section{North Sea late spring and summer spawners}

In contrast to species that spawn during the winter/early spring, the distribution of larvae at the end of the yolksac stage in species such as sprat (spring/ early summer spawner) and horse mackerel (summer spawner), will largely overlap with the spawning location of the adults. Drift durations in these species (one to two weeks) were predicted to be modest (Figs. 3 and 4 ) and the factor of increase in spreading (final spreading area relative to the spawning area) was less than two (Fig. 6). Thus, spawning aggregations will tend to yield "larval aggregations" in these warmer water spawners. Pelagic species, such as sprat and horse mackerel, are not as tightly coupled to topographic (bottom) features for spawning compared to demersal fish species, such as cod and plaice, but may target mesoscale (20 to $200 \mathrm{~km}$ ) hydrographic structures such as frontal zones due to aggregations of potential prey in these areas (Kiørboe et al., 1988; Riegman et al., 1990; Munk et al., 1999; Floeter, 2005). Moreover, in contrast to demersal species such as plaice and cod that fuel spawning from lipid stores accrued during summer feeding, small pelagic fish can augment the energy utilized for reproduction by feeding during the spawning season. Similar to other small pelagic fish, sprat larvae, juveniles and adults are zooplanktivorous, and, in many situations, adults feed on the same copepod species (albeit larger life stages) as their progeny (Dickmann, 2005). Thus, suitable habitats for adult feeding and spawning would also likely be suitable habitats for first-feeding larvae. Indeed, the high abundances of sprat eggs and larvae often found within North Sea frontal zones (Munk, 1993; Kanstinger and Peck, 2009) is probably due to a mixture of convergent zone aggregation (physics of water masses) and the presence of local adult/spawning aggregations.

Unlike sprat, horse mackerel is only a seasonal resident within the North Sea. In April, horse mackerel migrate into the southern North Sea, reaching southern Norway by August. Peak spawning has been observed in May and July and reproductive activity appears to be restricted to the Channel and southern North Sea (ICES, 2007). Interestingly, this species avoids waters that are $<10^{\circ} \mathrm{C}$ and, although post-spawning adults are often found in the central North Sea, Skagerrak and Kattegat, horse mackerel leaves the North Sea in the fall and overwinters further south. Given the specific life history strategy of horse mackerel and the relatively rapid development rate and short drift distances of early life stages, inter-annual variability in (climate-driven) abiotic factors may have a much larger impact on other life stages of this species (e.g. by changing the magnitude and timing of immigration of adults to North Sea spawning grounds (Reid et al., 2001, Iversen et al., 2002). Specifically, changes in the atmospheric pressure patterns since 1988 (high NAO index values) may have increased the northern advection of water masses, sea surface temperatures in the spring and summer months and prey production, which all assist (and perhaps lengthen) the annual migration of this species to the North Sea (Reid et al., 2001, Iversen et al., 2002). 


\section{Life history scheduling and impacts of climate variability}

Successful life history strategies of marine fish must allow connectivity between habitats for successive developmental stages (e.g. spawning adults, eggs, larvae, juveniles and mature adults) (Harden-Jones, 1968; Rijnsdorp et al., 2009). Most temperate marine fish produce multiple batches of eggs, utilize photothermal cues to initiate spawning (e.g. Lam, 1983) and can be relatively long-lived. Our simulations were not designed to capture all potential inter-specific differences but focused on illustrating differences in basic drift characteristics of eggs and larvae of North Sea marine fish species that have different peak spawning times and different developmental physiologies (impacts of temperature on development rate, Fig. 2). It is important to note that interspecific differences in transport patterns could arise from a variety of other (not tested) factors. For example, differences in egg buoyancy (Coombs et al., 1990 and 2004) and the resulting change in depth distribution of eggs and larvae would have a large impact on distances traveled regardless of the spawning season.

Our simulations suggested that inter-annual variability in water temperatures was greatest during March, the peak spawning time for Atlantic cod and the final period of spawning by plaice in the southern North Sea. Clear coupling between physical processes (temperatures and water circulation patterns impacting eggs and yolksac larvae) and atmospheric climate patterns (winter NAO index) was observed. Specifically, differences in the drift duration in Atlantic cod were significantly correlated with the NAO. Drift direction was primarily to the east (towards nursery areas in the German Bight) but north-south drift distances dominated in some years, which was related to the NAO index (particularly for sprat). In general, our North Sea simulations suggested that the largest variability in water temperature (and thus the duration of transport prior to first feeding of marine fish species) appears to occur in the early spring. Drift patterns also differed between known spawning grounds of demersal fish (Dogger Bank vs. Southern Bight).

However, it is important to note that our simulations cannot determine whether the potential impacts of variability in climate-driven factors (such as temperature) will be offset (mediated) by other aspects of species life history strategy that directly influence eggs and young larvae (e.g. spawning at different times of the year or spawning for protracted periods of time). For example, although variability in the timing of spawning by plaice and Atlantic cod was reported to be low by Cushing (1969), more recent studies on Atlantic cod suggest that the timing of spawning may be quite flexible (Lawson and Rose, 2000). Flexibility in the timing of spawning migrations was recently demonstrated for European flounder (Plactichthys flesus) for which earlier migrations occurred in cold years in association with very negative NAO index values (Sims et al., 2005). Clearly, potential impacts of climate variability on single species will be best investigated using IBMs with far greater biological complexity and realism that incorporate spawner demographics and exogenously feeding life stages. Comparisons of life history attributes and sensitivity to climate impacts could thus be explored based on projections of growth and survival rates (e.g. see Daewel et al., 2008). Nevertheless, our general (interspecific) results for eggs and yolksac larvae support the findings of Beare et al. (2004) and Heath (2005) who reported reductions in winter and early spring spawners (such as Atlantic cod and plaice) and increases in warmer-water species such as horse mackerel, sprat and other small pelagics in the North Sea.

\section{ACKNOWLEDGEMENTS}

We are grateful to Andreas Lehmann (IFM-Geomar, Kiel, Germany) for providing monthly values of the North Atlantic Oscillation. We would also like to thank Ute Daewel for informative discussions regarding climate impacts on drift trajectories and for her assistance with graphics. Two anonymous reviewers provided helpful comments on the structure and content of this manuscript. This research was funded by the European Union Specific Targeted Research Project "RECLAIM" (EU contract \#044133).

\section{REFERENCES}

Alheit, J., R. Voss, V. Mohrholz and R. Hinrichs. - 2007. Climate drives anchovies and sardines into North Sea. GLOBEC Newsletter, 13(2): 77-78.

Backhaus, J.O. - 1985: A three-dimensional model for the simulation of shelf sea dynamics. Deutsche Hydrographische Zeitschrift, 38: 165-187.

Beaugrand, G., K.M. Brander, J.A. Lindley, S. Souissi and P.C. Reid. - 2003. Plankton effect on cod recruitment in the North Sea. Nature, 426:661-664. 
Beare, D., F. Burns, A. Greig, E.G. Jones, K. Peach, M. Kienzle, E. McKenzie and D.G. Reid. - 2004. Long-term increases in prevalence of North Sea fishes having southern biogeographic affinities. Mar. Ecol. Prog. Ser., 284: 269-278.

Coombs, S.H., J.H. Nichols and C.A. Fosh. - 1990. Plaice eggs (Pleuronectes platessa) in the southern north sea: abundance, spawning area, vertical distribution, and buoyancy. ICES $J$. Mar. Sci., 47(2):133-139.

Coombs, S.H., G. Boyra, L.D. Rueda, A. Uriarte, M. Santos, D.V.P. Conway and N.C. Halliday. - 2004. Buoyancy measurements and vertical distribution of eggs of sardine (Sardina pilchardus) and anchovy (Engraulis encrasicolus). Mar. Biol., 145:959-970.

Cushing, D.H. - 1969. The regularity of the spawning season of some fishes. J. Cons. Int. Explor. Mer., 33: 81-92.

Daan, N., H. Gislason, J.G. Pope and J.C. Rice. - 2005. Changes in the North Sea fish community: evidence of indirect effects of fishing? ICES J. Mar. Sci., 62: 177-188.

Daewel, U., M.A. Peck, W. Kühn, M.A. St. John, I. Alekseeva and C. Schrum. - 2008. Coupling ecosystem and individual-based models to simulate the influence of environmental variability on potential growth and survival of larval sprat (Sprattus sprattus L.) in the North Sea. Fish. Oceanogr., 17: 333-351.

Dickmann, M. - 2005. Feeding ecology of sprat (Sprattus sprattus L.) and sardine (Sardina pilchardus W.) larvae in the Baltic Sea and in the North Sea. Doctor rerum naturalium, Univ. Rostock, Rostock, Germany, 1-97.

Edwards, K.P., J.A. Hare, F.E. Werner and H. Seim. - 2007. Using 2-dimensional dispersal kernels to identify the dominant influences on larval dispersal on continental shelves. Mar. Ecol. Prog. Ser., 352: 77-87.

Ellertsen, B., P. Fossum, P. Solemdal and S. Sundby. - 1989. Relation between temperature and survival of eggs and first-feeding larvae of northeast Arctic cod (Gadus morhua L.). Rapp. P.V. Reun. Cons. Int. Explor. Mer., 191: 209-219.

Floeter, J. - 2005. An investigation of key processes affecting trophic interactions in the North Sea fish assemblage and their significance for multi species fisheries assessment. $\mathrm{Ph}$. D Thesis, Univ. Hamburg.

Fox, C.J., A.J. Geffen and R.D.M. Nash. - 2003.Temperaturedependent development rates of plaice (Pleuronectes platessa L.) eggs from the Irish Sea. J. Plankton Res., 25: 1319-1329.

Fox, C.J., M. Taylor, M. Dickey-Collas, P. Fossum, G. Kraus, N. Rohlf, P. Munk, C.J.G. van Damme, L.J. Bolle, D.L. Maxwell, J. Peter and P.J. Wright. - 2008. Mapping the spawning grounds of North Sea cod (Gadus morhua) by direct and indirect means. Proc. R. Soc. B, 275: 1543-1548.

Geffen, A.J., C.J. Fox and R.D.M. Nash. - 2006. Temperature-dependent development rates of cod Gadus morhua eggs. J. Fish Biol., 69: 1060-1080.

Harden-Jones, F.R. - 1968. Fish Migration. Edward Arnold, London.

Harding, D, J.H. Nichols and D.S. Tungate. - 1978. The spawning of the plaice (Pleuronectes platessa L.) in the southern North Sea and English Channel. Rapp. P.V. Reun. Cons. Int. Explo. Mer., 172:102-113 499

Heath, M.R. - 2005. Changes in the structure and function of the North Sea fish foodweb, 1973-2000, and the impacts of fishing and climate. ICES J. Mar. Sci., 62(5): 847-868.

Hoarau, G., A.D. Rijnsdorp, H.W. Van der Veer, W.T. Stam and J.L. Olsen. - 2002. Population structure of plaice (Pleuronectes platessa L.) in northern Europe: microsatellites revealed largescale spatial and temporal homogeneity. Mol. Ecol., 11: 11651176.

Houde, E.D. - 2008. Emerging from Hjort's shadow. J. Northw. Atl. Fish. Sci., 41: 53-70.

Hunter, E., J.D. Metcalfe and J.D. Reynolds. - 2003. Migration route and spawning area fidelity by North Sea plaice. Proc. $R$. Soc. Lond. B, 270: 2097-2103.

ICES. - 2005. Spawning and life history information for North Atlantic cod stocks. ICES Coop. Res. Rep. 274: 1-152.

ICES. - 2007. Report of the working group on the assessment of mackerel, horse mackerel, sardine and anchovy (WGMHSA). ICES CM 2007/ACFM: 31.

Iles, T.D. and M. Sinclair. - 1982. Atlantic herring: stock discreteness and abundance. Science, 215: 627-633.

Iversen, S.A.D., M. Skogen and E. Svendsen. - 2002. Availability of horse mackerel (Trachurus trachurus) in the north-eastern North Sea, predicted by the transport of Atlantic water. Fish.
Oceanogr. 11(4): 245-250.

Jordaan, A.D. and L.J. Kling. - 2003. Determining the optimal temperature range for Atlantic cod (Gadus morhua) during early life. In: H.I. Browman and A.B. Skiftesvik. (eds.), The Big Fish Bang, pp. 45-62. Institute of Marine Research, Bergen.

Kalnay, E., M. Kanamitsu, R. Kistler, W. Collins, D. Deaven, L. Gandin, M. Iredell, S. Saha, G. White, J. Woollen, Y. Zhu, M. Chelliah, W. Ebisuzaki, W. Higgins, J. Janowiak, K.C. Mo, C. Ropelewski, J. Wang, A. Leetmaa, R. Reynolds, R. Jenne and D. Joseph. - 1996. The NCEP/NCAR 40-Year Reanalysis Project. Bull. Amer. Meterol. Soc., 77(3): 437-471.

Kanstinger, P. and M.A. Peck. - 2009. Co-occurrence of European sardine (Sardina pilchardus), anchovy (Engraulis encrasicolus) and sprat (Sprattus sprattus) larvae in southern North Sea habitats: Abundance, distribution and biochemical-based condition. Sci. Mar., 73S1: 141-152.

Kiørboe, T., P. Munk, K. Richardson, V. Christensen and H. Paulsen. - 1988. Plankton dynamics and larval herring growth, drift and survival in a frontal area. Mar. Ecol. Prog. Ser., 44: 205-219.

Knutsen, H., C. André, P.E. Jorde, M.D. Skogen, E. Thuróczy and N.C. Stenseth. - 2004. Transport of North Sea cod larvae into the Skagerrak coastal populations. Proc. R. Soc. Lond. B, 271: $1337-1344$.

Lam, T.J. - 1983. Environmental influences on gonadal activity in fish. In: W.S. Hoar, D.J. Randall and E.M. Donaldson (eds.), Fish Physiology, pp. 65-116.vol. IXB. Academic Press, New York.

Lawson, G.L. and G.A. Rose. - 2000 Small-scale spatial and temporal patterns in spawning of Atlantic cod (Gadus morhua) in coastal Newfoundland waters. Can. J. Fish. Aquat. Sci., 57: 1011-1024.

Miller, T.J. - 2007. Contribution of individual-based coupled physical-biological models to understanding recruitment in marine fish populations. Mar. Ecol. Prog. Ser., 347: 127-138.

Munk, P. - 1993. Differential growth of larval sprat Sprattus sprattus across a tidal front in the eastern North Sea. Mar. Ecol. Prog. Ser., 99: 17-27.

Munk, P., P.O. Larsson, D.S. Danielssen, E. Moksness. - 1999. Variability in frontal zone formation and distribution of gadoid fish larvae at the shelf break in the northeastern North Sea. Mar. Ecol. Prog. Ser., 177: 221-233.

Nissling, A. - 2004. Effects of temperature on egg and larval survival of cod (Gadus morhua) and sprat (Sprattus sprattus) in the Baltic Sea - implications for stock development. Hydrobiologia, 514: $115-123$

Perry, A.L., P.J. Low, J.R. Ellis and J.D. Reynolds. - 2005. Climate change and distribution shifts in marine fishes. Science, 308: 1912-1915.

Petereit, C., H. Haslob, G. Kraus and C. Clemmesen. - 2008. The influence of temperature on the development of Baltic Sea sprat (Sprattus sprattus) eggs and yolk sac larvae. Mar. Biol., 154: 295-306.

Pipe, R.K. and P. Walker. - 1987. The Effect of temperature on development and hatching of scad, Trachurus trachurus L., eggs. J. Fish Biol., 31: 675-682

Pohlmann, T. - 1996. Predicting the thermocline in a circulation model of the North Sea. Part I: Model description, calibration, and verification. Cont. Shelf Res., 16: 131-146.

Pohlmann, T. - 2006. A meso-scale model of the central and southern North Sea: consequences of an improved resolution. Cont. Shelf Res., 26: 2367-2385.

Preisendorfer, R.W. - 1988. Principal Component Analysis in Meteorology and Oceanography, Elsevier Science Publishers BV

Reid, P.C., M. Borges, E. Svendsen. - 2001. A regime shift in the North Sea circa 1988 linked to changes in the North Sea horse mackerel fishery. Fish. Res., 50: 163-171.

Riegman, R., F. Cohjn, J.F.P. Malschaert, H.T. Kloosterhuis and G.C. Cadee. - 1990. Assessment of growth rate limiting nutrients in the North Sea by the use of nutrient-uptake kinetics. Neth. J. Sea Res., 26: 53-60.

Rijnsdorp A., M.A. Peck, G.H. Engelhard, C. Möllmann and J.K. Pinnegar. - 2009. Resolving the effect of climate change on fish populations. ICES J. Mar. Sci., (in press)

Rogers, S., R. Stocks and A. Newton. - 2001. North Sea Fish and Fish. Tech. Rep., 003: 1-72.

Ryland, J.S. and J.H. Nichols. - 1975. Effect of temperature on the 


\section{6 - M.A. PECK et al.}

embryonic development of the plaice Pleuronectes platessa. $J$. Exp. Mar. Biol. Ecol., 18: 121-137.

Sims, D.W., V.J. Wearmouth, M.J. Genner, A.J. Southward and S.J. Hawkins. - 2005. Low-temperature-driven early spawning migration of a temperate marine fish. J. Animal Ecol., 73: 333341.

Thompson, B.M., S.P. Milligan and J.H. Nichols. - 1981. The development rates of sprat (Sprattus sprattus L.) eggs over a range of temperatures. ICES Council Meeting., 1981/H:15.

Visser, A.W. - 1997. Using random walk models to simulate the vertical distribution of particles in a turbulent water column. Mar. Ecol. Prog. Ser., 158: 275-281.

von Westernhagen, H. - 1970. Erbrütung der Eier von Dorsch (Gadus morhua), Flunder (Pleuronectes flesus) und Scholle (Pleuronectes platessa) unter kombinierten Temperatur- und Salzgehaltsbedingungen. Helgoländer wiss. Meeresunters., 21: 21-102.

Received November 16, 2008. Accepted July 17, 2009.

Published online October 5, 2009. 